\title{
Clarence Darrow and His Ties to Kansas
}

\author{
M.H. Hoeflich*
}

\section{INTRODUCTION}

The period from the end of the Civil War to the beginning of the Second World War was, in many respects, an age of giants in the law. This period saw the transformation of legal education through the efforts of Christopher Columbus Langdell and James Bar Ames at Harvard; remarkable legal development through the efforts of judges like John Marshall Harlan, Oliver Wendell Holmes, Jr., Benjamin Cardozo, and Louis Brandeis; and a revolution in the law practice through the lawfirm-building efforts of Paul Drennan Cravath, Elihu Root, and David Dudley Field. Yet, when we think of this era in the law, we do not think of it as a golden age of litigation and advocacy. The preceding generations that included legendary courtroom advocates like Rufus Choate and Daniel Webster tend to hold that place in most lawyers' minds. However, this period did produce one courtroom advocate who has become legendary: Clarence Darrow.

When we think of Darrow, we generally associate him with his great courtroom battles on behalf of labor unions and union leaders, and we think of him as the defender of criminal defendants like Leopold and Loeb. ${ }^{1}$ Most of all, when we think of Darrow, we think of his performance in the Scopes evolution trial when he defeated the great fundamentalist politician and frequent presidential candidate, William Jennings Bryan. ${ }^{2}$ When we think of Darrow, we also think of Illinois and Chicago, where he spent most of his adult life. In this article I will

\footnotetext{
Kane Professor of Law, University of Kansas School of Law. The author wishes to thank Ms. Jen Haaga, KU Law class of 2010, for her assistance in producing this Article.

1. Darrow has been the subject of numerous biographies and articles. See, e.g., CLARENCE DARROW, THE STORY OF MY LIFE (1932) [hereinafter DARROW, MY LIFE]; RICHARD J. JENSEN, Clarence Darrow: The Creation of an AmericAn Myth (1992); KeVin Tierney, Darrow: A Biography (1979); ARTHUR WEINBERG \& LilA WEINBERG, ClarENCE DARRow: A SENTIMENTAL REBEL (1980). In addition, Professor Douglas Linder at the University of Missouri-Kansas City School of Law maintains an excellent webpage on Darrow at http://www.law.umkc.edu/faculty/ projects/ftrials/DARROW.htm (last visited Feb. 13, 2009).

2 See infra note 36 and accompanying text.
} 
discuss another aspect of Darrow's life - that of his literary endeavorsand I want to speak of another place with which his life was connected: Kansas. It was Kansas, and especially Girard, a small town in Southeastern Kansas and the home of the Haldeman-Julius Publishing Company, that played a large, albeit almost forgotten, role in Darrow's life and literary career.

\section{FIRST CONTACTS}

In the past eighty years, Clarence Darrow has become an American icon. His biographical details are well known. He was born in a small Northern Ohio town in $1857^{3}$ to a somewhat unconventional family. His father, Amirus, had attended Allegheny College to study theology, but lost his faith and became an atheist at a time when few Americans were. ${ }^{4}$ Amirus then worked as a carpenter until 1864, when, at age forty-six, he decided to enroll in law school at the University of Michigan. ${ }^{5}$ After a year, he decided the law was not for him and returned to the family home. ${ }^{6}$ Even the house in which Darrow was raised was unconventional: it was an octagonal house designed by O.S. Fowler, then the most prominent phrenologist in the United States. ${ }^{7}$

Given the unorthodox nature of his childhood, it is not at all surprising that Darrow never had great respect for either the political or social status quo. Although he did not excel in school, he followed his father's example and enrolled at Allegheny College; like his father, he left college without a degree. ${ }^{8}$ For a short period thereafter he worked with his father as a carpenter and then considered teaching as a career, but neither satisfied him. ${ }^{9}$ In 1877, he entered law school at the University of Michigan. ${ }^{10}$ Once again, he left without a degree and began working at a law office in Youngstown, Ohio, as an apprentice. ${ }^{11}$ After several months he sat for the Ohio bar exam and was successful; he was admitted to the bar in $1878 .^{12}$

3. TIERNEY, supra note 1 , at 3 .

4. Id. at 5-6.

5. Id. at 14 .

6. Id.

7. Id. at 7.

8. Id. at 19-20.

9. Id. at 20 .

10. Id. at 21-22.

11. Id. at 22 .

12. Id. at 23 . 
Darrow's early years at the bar were not unorthodox at all. $\mathrm{He}$ returned home to Kinsman, Ohio, set out his shingle, and married soon thereafter. ${ }^{13}$ But like many young lawyers starting out on his own, he acquired few clients and realized he could not continue in practice and provide for his family unless something changed. ${ }^{14}$ It was at this point Darrow had his first contact with Kansas. According to Kevin Tierney, one of Darrow's biographers, Darrow considered moving to McPherson, Kansas, to set up a practice there. ${ }^{15}$ This was, apparently, a popular location for those young lawyers seeking to follow Horace Greeley's advice to "go west."16

At the time Darrow considered his move, McPherson was a prosperous town of about two thousand. ${ }^{17}$ It was the county seat of McPherson County, which had been settled by several waves of emigrants, including the Chicago Swedish Colony that had founded Lindsborg, Kansas, in 1868. ${ }^{18}$ More importantly, in 1871, the Ashtabula Colony had been formed in Ashtabula, Ohio, to establish a new town in McPherson County, known as King City, Kansas, after the president and organizer of the colony, E.L. King. ${ }^{19}$ In 1872, twenty-six Ohioans traveled to McPherson County and set up their new town. ${ }^{20}$ Within a decade, King City was in decline and most of the colonists had moved to nearby McPherson. ${ }^{21}$ Thus, Darrow most likely knew some of the Kansas emigrants and something of McPherson and its business community. We do not know why Darrow chose not to move to McPherson. He may have decided there were already too many lawyers in the town or, perhaps, he simply felt the town was too rustic for his ambitions. Whatever the reason, Darrow's first contact with Kansas did not prove to be of lasting significance.

As is well known, Darrow and his family moved to Chicago, the city which was to be his home and headquarters, despite some minor

\footnotetext{
13. Id. at $23-24$.

14. Id. at 24 .

15. Id.

16. Id.; see also Coy F. Cross, Go West Young MAn! Horace Greeley's Vision for AMERICA (1995).

17. See Blue Skyways, Kansas Counties, McPherson, http://skyways.lib.ks.us/counties/MP/ (last visited March 9, 2009).

18. William G. Cutler, History of the State of Kansas (1993), available at http:// www.kancoll.org/books/cutler/mcpherson/mcpherson-co-p1.html.

19. William G. CUTler, History OF THE STATE OF KANSAS, available at http:// www.kancoll.org/books/cutler/mcpherson/mcpherson-cop1.html\#ASHTABULA_COLONY_AND_KING_CITY.

20. Id.

21. Id.
} 
interludes, until his death in $1938 .^{22}$ In Chicago, Darrow began to associate himself with progressive politics, an association which led quickly to the most important personal and professional relationship of his life. ${ }^{23}$ His partner in this relationship was John P. Altgeld, a rising political $\operatorname{star}^{24}$ and one of the most tragic figures in Illinois history. ${ }^{25} \mathrm{He}$ served as a judge and eventually as governor of Illinois. ${ }^{26}$ He was a progressive politician who was committed to bettering the lives of the poor in Illinois at a time when most politicians were both corrupt and pro-business. ${ }^{27}$ Soon after Darrow and Altgeld met, they became close friends and political allies. ${ }^{28}$ Darrow served as Altgeld's chief political lieutenant and managed his political campaigns. ${ }^{29}$ Altgeld served as Darrow's mentor and patron. ${ }^{30}$ In this capacity Altgeld first arranged for Darrow to be appointed as assistant corporation counsel in Chicago and, later, as in-house counsel to the Chicago \& Northwestern Railway. ${ }^{31}$ Throughout the long period in which Darrow held these positions he worked tirelessly for Altgeld and his political allies and, remarkably, also conducted a litigation practice on the side. ${ }^{32}$ The financial security provided by the government and railroad positions allowed Darrow to pick and choose his clients; he did so with a clear aim of becoming known as a progressive, if not left-wing, champion. ${ }^{33}$ It was during this period that Darrow first gained the attention of national figures like the great socialist Eugene V. Debs. ${ }^{34}$ Finally, in 1894, Darrow left the railroad, entered the first of his numerous law partnerships, and began the first phase of his rise to national prominence. ${ }^{35}$

From 1894 to 1925 , he served as defense counsel in a long string of highly publicized cases, including lead defense counsel for the Scopes evolution trial in Tennessee. ${ }^{36}$ The earliest of these cases were those that

22. TIERNEY, supra note 1 , at 34-45.

23. Id. at $41-76$.

24. Id.

25. DARROW, My LIFE, supra note 1, at 105-11.

26. Id. at 96,100 .

27. Id. at 107-11.

28. TIERNEY, supra note 1 , at 42.

29. Id. at $42-45,54$.

30. Id. at $42-45$.

31. Id. at 53,57

32. Id. at $53-58$.

33. Id. at 89-93.

34. Id. at 90-116.

35. Id. at 99-100.

36. See generally Irving StOne, Clarence Darrow FOR the Defense (1941) (a highly romanticized account of Darrow's trials); PHYLlis VINE, ONE MAN's CASTLE: ClARENCE DARROW IN DEFEnSE OF THE AMERICAN DREAM (2004) (detailing Darrow's defense of Dr. Ossian Sweet, a 
came to Darrow through his friendship with Debs and other socialist and labor leaders. During this period, Darrow was lead counsel in In re Debs ${ }^{37}$ the federal government prosecution of the socialist presidential candidate. ${ }^{38}$ He was also lead counsel in both the criminal case against Thomas Kidd, the president of the Woodworkers' Union, and the criminal case against "Big" Bill Haywood, the president of the Western Federation of Miners who was accused of masterminding an Idaho bombing. ${ }^{39}$ In these and other cases during the period, Darrow established a pattern of successful defenses, bringing him national acclaim from the left and condemnation from the right. More importantly, these cases allowed him to establish a litigation style uniquely his own. Darrow did not dwell on legal technicalities. Instead, he turned the courtroom into a Chatauqua; his courtroom speeches, which often went on for hours, were masterpieces of rhetoric, literary allusions, and philosophical asides. Darrow was a master at crossexamination and confounding witnesses. Juries loved him. He was also a seeker of publicity, encouraging the press to cover his courtroom performances. It was also during this period that Darrow began to make his own efforts at literature, not only writing magazine and newspaper articles, but also novels. While Darrow had some success as a writer, it was limited. As will become evident, Darrow's lack of literary success would be the factor that eventually led him to Kansas and Emanuel Haldeman-Julius.

The United States' entry into the First World War split American socialists into two camps. ${ }^{40}$ One camp, led by Debs, opposed American intervention in the European war. ${ }^{41}$ The other camp, in which Darrow found himself, supported Woodrow Wilson's determined efforts to send American forces to help the French and the British. ${ }^{42}$ Darrow's siding with Wilson led to a decline in his labor connections. His opposition to Debs and the anti-war socialists, as well as a controversial result in a case in which Darrow had defended two brothers - the McNamaras, on murder charges connected with labor agitation-soon led to the virtual collapse of Darrow's labor practice. ${ }^{43}$ For a period, Darrow was at loose ends, but this soon changed and Darrow began to use his courtroom

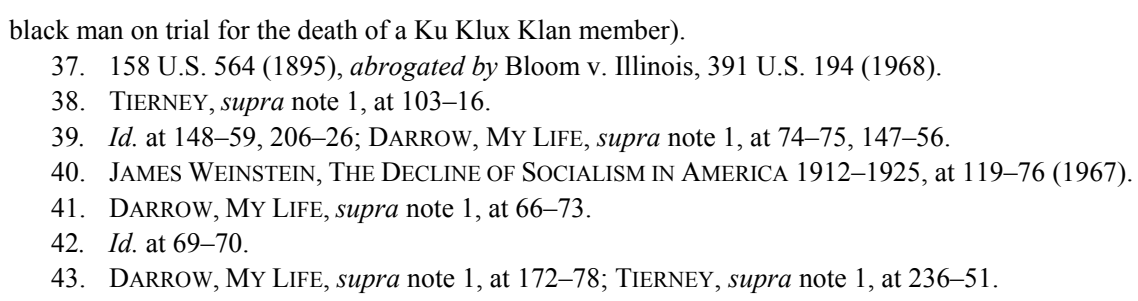


talents in a series of criminal cases. One of the cases was the prosecution of Leopold and Loeb - often considered the greatest criminal trial of the period. $^{44}$ By the early 1920s, when Darrow was already in his sixties, he had regained the national stage and soon took on his greatest case, the defense of John T. Scopes on a charge of having violated a statute which forbade the teaching of evolution in Tennessee schools. ${ }^{45}$ That case was the highpoint of Darrow's legal career. Although Darrow and his team lost the case, they won the battle for the nation's mind and heart. ${ }^{46}$ Darrow's cross-examination of the great William Jennings Bryan was both brilliant and devastating. ${ }^{47}$ Bryan died just two days after the trial ended, a broken man. ${ }^{48}$ In addition, two Kansans were at that trial who would play a major role in the next phase of Darrow's life: Emanuel and Marcet Haldeman-Julius of Girard, Kansas, proprietors of the HaldemanJulius Publishing Company. ${ }^{49}$

\section{GIRARD \& HALDEMAN-JULIUS PUBLISHING}

Girard, Kansas, is the county seat of Crawford County. ${ }^{50}$ It borders Missouri on the east and is south of Fort Scott, Kansas. Since it was founded in 1868, it has always been a small town. ${ }^{51}$ It sits in the middle of deep coal country and its economy has, throughout its existence, depended upon the coal mining industry. ${ }^{52}$ But for the first half of the twentieth century, it also was home to one of the most important publishing enterprises in the United States. ${ }^{53}$ In 1897, J.A. Wayland, a wealthy businessman and socialist, founded the Appeal to Reason newspaper in Girard. ${ }^{54}$ In its heyday, the Appeal to Reason boasted a

44. DARRow, My LiFe, supra note 1, at 226-43; TIERNEY, supra note 1, at 320-51. Leopold and Loeb were the sons of two of America's wealthiest families and were charged with deliberate and cold-blooded murder. TIERNEY, supra note 1, at 320 .

45. DARROW, MY LIFE, supra note 1, at 244-65; TIERNEY, supra note 1, at 362-73.

46. They also were immortalized in a film version of the Scopes trial which remains popular to this day. See Inherit the Wind (United Artists 1960).

47. DARROW, MY LIFE, supra note 1, at 266-67.

48. See id. at 269-70.

49. Albert Mordell, Clarence Darrow, Eugene V. Debs and Haldeman-Julius 9 (E. Haldeman-Julius ed., 1950).

50. A Brief History of Girard, KAN. PRES., Winter 2009, at 3 [hereinafter Girard].

51. Id.

52. See id.

53. Id.; Elliott Shore, Talkin' Socialism: J.A. Wayland and the Role of the Press IN AMERICAN RADICALISM, 1890-1912, at 8 (1988).

54. SHORE, supra note 53, at 7-31; Girard, supra note 50, at 3; David Paul Nord, The Appeal to Reason and American Socialism, 1901-1920, 1 KAN. HIST.: J. CENT. PlaINS 75, 75-78 (1978); David L. Sterling, The Federal Government v. The Appeal to Reason, 9 KAn. Hist.: J. CEnT. Plains 
national subscriber base of seven hundred thousand, by far the largest circulation of any socialist periodical in the United States. ${ }^{55}$ Wayland was a firebrand - a supporter of radical labor, Eugene V. Debs, and other socialist causes. ${ }^{56}$ He was also a frequent critic of the federal government, particularly of the federal judiciary and sitting presidents. This later brought him into direct conflict with the federal government and resulted in frequent prosecutions for all manner of violations of federal law. ${ }^{57}$ Theodore Roosevelt, the target of many of Wayland's most vicious attacks, referred to the newspaper as a "vituperative organ of pornography[,] anarchy, and bloodshed." "58 By 1912, Wayland and his senior staff were all targets of federal investigations and prosecutions. ${ }^{59}$ The tension this caused had its effect on Wayland; that year he committed suicide. ${ }^{60}$ For the next three years the newspaper was run by his subordinates, but in 1915, the Appeal to Reason recruited a rising young star of socialist journalism: Emanuel Julius.

Emanuel was a child of Philadelphia and an autodidact. ${ }^{61}$ By 1915, he had reported for and edited various socialist publications in New York, Chicago, and California. ${ }^{62} \mathrm{He}$ had worked with journalistic luminaries such as Carl Sandburg, the great poet and Lincoln biographer, and Upton Sinclair. ${ }^{63}$ Emanuel also first met Clarence Darrow in 1913 while Emanuel was editor of the Western Comrade and Darrow was on trial for jury tampering and bribery. ${ }^{64}$ Soon after their first meeting, Emanuel was called to Girard to reinvigorate the Appeal to Reason, ${ }^{65}$

31, 31 (1986). See generally WeINSTEIN, supra note 40, at 84-93 (discussing the socialist press of the period).

55. See WeInSTEIN, supra note 40, at 94-102 (describing the circulation figures for American socialist periodicals). Pages 96 and 97 specifically detail the circulation of the Appeal to Reason as 761,747 in 1913 and as 529,132 from 1917-1918.

56. SHORE, supra note 53 , at $8-9$.

57. Sterling, supra note 54, at 31-42.

58. Nord, supra note 54 , at 75.

59. Sterling, supra note 54 , at $37-40$.

60. Id.

61. See generally E. HaLdEMAN-Julius, My FiRSt 25 YeARs (1949) (an autobiography); E. HALDEMAN-JUlius, My SECOND 25 YeARs (1949) (an autobiography); E HALDEMAN-Julius, ThE FIRST HUNDRED MILLION (1974) (A “'How To' Instruction Manual for anyone who uses words to make a living."); M.H. Hoeflich, Emanuel and Marcet Haldeman-Julius: An Innovative Partnership in Publishing, in JOHN Brown to Bob DOlE: MOVERS AND SHAKers IN KANSAS History 193 (Virgil W. Dean ed., 2006) (providing an overview of the business partnership between Emanuel Haldeman-Julius and his wife, Marcet); Andrew Neilson Cothran, The Little Blue Book Man and the Big American Parade: A Biography of Emanuel Haldeman-Julius (1966) (Ph.D. Dissertation, Univ. of Md.) (discussing the life of Emanuel Haldeman-Julius).

62. Hoeflich, supra note 61, at 195.

63. E. HALDEMAN-JULIUS, MY FIRST 25 YEARS, supra note 61, at 13-25.

64. Id. at $25-28$.

65. Id. at 13; Mark Scott, The Little Blue Books in the War on Bigotry and Bunk, 1 KAN. HIST.: 
which had been faltering since Wayland's death. ${ }^{66}$ Within a few years, not only had Emanuel taken over the newspaper, but he had also begun an ambitious and novel publishing program which ultimately became the Little Blue Books - a series of inexpensive paper-bound volumes designed for the working class that eventually sold more than five hundred million copies in over six thousand titles. ${ }^{67}$ As part of this publishing enterprise, Emanuel also became Darrow's principal publisher. ${ }^{68}$

When Emanuel came to Girard, he not only found a newspaper and publishing business which would soon become his life's work, but he also found the woman who would become his wife, business partner, and co-worker. Marcet Haldeman was the daughter of a prominent Girard couple, Henry and Alice Addams Haldeman. ${ }^{69}$ Her father was both a doctor and president of a bank. ${ }^{70}$ Her mother was an officer of the bank and took over as president when her husband died. ${ }^{71}$ Marcet and her mother were not typical small town Kansans. Marcet's aunt was Jane Addams, the great Chicago social reformer, to whom Darrow had become close in Chicago. ${ }^{72}$ Marcet, herself, traveled to Pennsylvania to attend Bryn Mawr College, a stronghold of feminists; upon graduation, she moved to New York City to become an actress. ${ }^{73}$ Interestingly, Marcet and Emanuel lived in the same apartment building at the same time in New York City, but they never met. ${ }^{74}$ Very soon after Emanuel arrived in Girard, he and Marcet not only met, but married and combined their last names to become Emanuel and Marcet Haldeman-Julius. ${ }^{75}$

By 1919, Emanuel, with financing provided in part from Marcet, was able to take control and eventually full ownership of the Appeal to Reason and its publishing plant. ${ }^{76}$ During the three years from 1915 to 1918, Emanuel had already begun to change the Appeal to Reason,

J. Cent. Plains 155, 159 (1978).

66. See Sterling, supra note 54, at 41.

67. E. HALDEMAN-Julius, My First 25 YeARS, supra note 61, at 12-15; Scott, supra note 65, at $155-76$.

68. E. HALDEMAN-JUliUs, MY FIRST 25 YeARS, supra note 61, at 28-29.

69. Id. at 47; Girard, supra note 50, at 3; Scott, supra note 65, at 159-60.

70. Cothran, supra note 61 , at 49 .

71. See id. at 49-52; Girard, supra note 50, at 4.

72. Cothran, supra note 61, at 49-57.

73. Id. at 49-51; Scott, supra note 65, at 159 .

74. E. HALDEMAN-JULIUS, MY FirST 25 YeARS, supra note 61 , at 47.

75. Scott, supra note 65 , at 160 (speculating, based on information from the late Gene DeGruson, that it was at Jane Addams's prompting that Julius became Haldeman-Julius when he married Marcet).

76. Id. 
moving it away from investigative reporting and more toward literature and reviews. These changes were a foreshadowing of the far more radical changes to come. ${ }^{77}$ By 1918, the circulation of the Appeal to Reason had plummeted and its future financial viability was in question. ${ }^{78}$ Emanuel realized he had a massive printing plant capable of turning out not only a newspaper, but also books. This would allow him to establish a series of small, paper-bound volumes that he could sell cheaply. The limitations of his presses meant the books had to be quite small in dimensions and had to have thirty-two, sixty-four, or one hundred and twenty-eight pages. ${ }^{79}$ Originally, Emanuel called these the Appeal to Reason Library. ${ }^{80}$ But within a few years, the series became known as the Little Blue Books, named after the pale blue color of their covers. $^{81}$

Originally, Emanuel envisaged that the Little Blue Books would reprint abridged classics of Anglo-American literature. ${ }^{82}$ Among the first titles were an abridgement of Burton's translation of the Rubaiyat of Omar Khayyam and the works of Oscar Wilde. ${ }^{83}$ Within a short time, however, the list of titles had expanded to include scientific works, selfhelp treatises, political writings by men like Upton Sinclair, and, the most popular of all, tracts on sex. ${ }^{84}$ The price of these Little Blue Books ranged from twenty-five cents to ten cents to five cents each. ${ }^{85}$ At this price, the books were affordable to factory workers, farmers, coal miners, and young shop clerks. ${ }^{86}$ Emanuel's plan was to provide the means by which America's workers could give themselves the equivalent of a college education at a low cost. ${ }^{87}$ The books were advertised in major newspapers and magazines throughout the United States. ${ }^{88}$ A series of Little Blue Book stores, selling nothing but Haldeman-Julius publications, were opened in major American cities, and the books were even available in vending machines. ${ }^{89}$ By the time Emanuel died, his

77. Id. at $160-61$.

78. See WeINSTEIN, supra note 40 , at 90 .

79. Hoeflich, supra note 61, at 196.

80. Id. at 197.

81. Id.

82. See id. at 198; Cothran, supra note 61, at 129-31; Scott, supra note 65, at 164;

83. Scott, supra note 65 , at $162-64$.

84. E. Haldeman-Julius, The First Hundred Million, supra note 61, at 7-20; Hoeflich, supra note 61 , at 198 .

85. Scott, supra note 65 , at 164 .

86. Id.

87. See id. at 161-62.

88. E. HALdEMAN-Julius, The First HundRed Million, supra note 61, at 141-53.

89. E. Haldeman-Julius, Automatic Library_Phase I: The First Use of Vending Machines for 
company had published and sold more than three hundred million books and his list of Little Blue Books ran to nearly two thousand titles. ${ }^{90}$ In addition to the Little Blue Books, Haldeman-Julius published a number of larger format paperback books, known as the Big Blue Books, and several magazines on politics and other subjects. ${ }^{91}$ By the $1920 \mathrm{~s}$, Emanuel Haldeman-Julius had been nicknamed the "Henry Ford" of American publishing.

Although Emanuel was a brilliant businessman and marketing genius, he was not so successful in his personal life. It appears he treated his wife, Marcet, and his children not well at all - they often lived apart and Emanuel rarely provided sufficient financial support for them. ${ }^{92}$ In her letters, Marcet often complained of not having enough money for basic necessities, including heat in the winter. ${ }^{93}$ This drove her to take out loans in order to feed her family. But as the cliché goes, "every cloud has a silver lining." In this case the silver lining is the odd proposition Emanuel made to Marcet. While he would not give her additional funds to support her and his children, he was willing to pay her for any articles or books she might write and he could publish. ${ }^{94}$ Thus, financial exigency drove Marcet to become a prolific journalist and Blue Book writer. Most importantly, of the subjects about which she wrote during her life, law and trials were the most frequent. ${ }^{95}$ Thus, because of Emanuel's parsimony, Marcet came to write about Clarence Darrow and his courtroom triumphs. ${ }^{96}$

\section{THE DARROW-HALDEMAN-JULIUS COLLABORATION}

As mentioned earlier, Clarence Darrow and Emanuel HaldemanJulius first met in Los Angeles in 1913. ${ }^{97}$ At the time, Emanuel was the young editor of the Western Comrade and Darrow was fifty-six years old, a well-known courtroom lawyer, and on trial for bribing a jury. ${ }^{98}$

\footnotetext{
the Sale of Little Blue Books, 1938, reprinted in BIg BluE NewSL. No. 4, $26-27$ (2004); Cothran, supra note 61, at 194-98.

90. Cothran, supra note 61, at 427; Hoeflich, supra note 61, at 197.

91. Hoeflich, supra note 61, at 197.

92. Id. at 202; Cothran, supra note 61, at 208-10.

93. Cothran, supra note 61 , at 221-23.

94. Id.

95. Hoeflich, supra note 61, at 199.

96. Id.

97. Hoeflich, supra note 61 , at 199 . The most important source for the Darrow-HaldemanJulius relationship is MORDELL, supra note 49, at 3-21.

98. E. HALDEMAN-JULIUS, MY FirST 25 YeARS, supra note 61, at 24-26; TIERNEY, supra note 1 , at $252-75$.
} 
Kevin Tierney, one of Darrow's biographers, has characterized this period in Darrow's life as one of disgrace and depression. ${ }^{99}$ But even in disgrace, Darrow was an impressive figure who enjoyed the attentions paid him by his supporters. No doubt, the friendship between the aging lawyer and the young editor was welcome to them both and there seems no reason to doubt that, even after Darrow was acquitted and returned to Chicago and Emanuel left Los Angeles for Girard, this friendship continued, albeit at a distance. Certainly, Emanuel became one of Darrow's greatest supporters during the trial, which he covered extensively and sympathetically in the Western Comrade. ${ }^{100}$ Although Emanuel remained a strong supporter of Darrow, their business relationship did not truly start until 1925, the year of the Scopes evolution trial.

When Darrow joined the Scopes defense in 1925, he was sixty-eight years old, in semi-retirement, and spending his time less on law practice and more on lecturing and writing for literary and news periodicals. ${ }^{101}$ The trial itself was a national event because it was seen as the final battle between the fundamentalists, who took the Biblical account of the creation of the world and of humankind literally as both the word of God and as historical fact, and those who believed in Darwinian evolution and the relevance of modern science. ${ }^{102}$ Reporters, including such notables as H.L. Mencken, traveled to the small town of Dayton, Tennessee, to watch the fireworks - particularly the match-up of Darrow against the fundamentalist politician, candidate, and orator, William Jennings Bryan. ${ }^{103}$ This spectacle was simply irresistible to the HaldemanJuliuses. They climbed in their car and drove straight to Tennessee. Once in Dayton, they immediately set off to visit Darrow. ${ }^{104}$ They faithfully attended the court proceedings each day. ${ }^{105}$ Marcet assumed the role of reporter and Emanuel of promoter and publisher. ${ }^{106}$

The visit to Dayton led to a fast renewal of the friendship between Darrow and Emanuel. This, in turn, led to the Darrows' trip to Girard

\footnotetext{
99. TIERNEY, supra note 1 , at 257-58.

100. E. HALDEMAN-JULiUS, My FIRST 25 YEARS, supra note 61, at 24-25.

101. DARROW, MY LIFE, supra note 1, at 254-65; TIERNEY, supra note 1, at 362-73.

102. Those of us who live in Kansas know that the Scopes trial was far from the "final" battle over teaching evolution in American schools.

103. Marcet Haldeman-Julius, Impressions of the Scopes Trial, in MARCET HALDEMAN-JULIUS, Clarence Darrow's Two Great Trials: Reports of the SCOPES ANTi-Evolution CaSE AND THE Dr. SweEt Negro Trial 3, 14 (E. Haldeman-Julius ed., 1927). It is interesting that the entire text was written by Marcet, but the volume is "edited" by Emanuel.

104. Id. at 4; MORDELL, supra note 49, at 7.

105. See MORDELL, supra note 49 , at 9.

106. See id.
} 
and the Haldeman-Julius farm soon after the trial ended. ${ }^{107}$ This visit strengthened the friendship between the two men, and Darrow took the opportunity to flatter Marcet on her reporting. ${ }^{108}$ When one looks at the photographs taken of the two men during the Darrow visit to Girard, their friendship and mutual support shines through.

There can be very little doubt - both from his frequent praise of Darrow, and from the number of articles about Darrow and number of pieces by Darrow that began to appear in Haldeman-Julius publications - that Emanuel made it his mission to promote Darrow and bring his words to as large an audience as possible. ${ }^{109}$ This suited Darrow as well.

Indeed, Darrow and Emanuel had much to offer each other. At sixty-eight years old, Darrow was less concerned about earning a living as a lawyer than about leaving a permanent legacy of his writings and speeches. ${ }^{110}$ For years Darrow had hired stenographers to transcribe his courtroom performances and, apparently, was not above editing the transcripts to improve them when necessary. ${ }^{111}$ Emanuel was a dream come true for Darrow. By 1925, most of Darrow's publications were out of print and none had achieved the literary success he had long craved. ${ }^{112}$ Emanuel, the "Henry Ford" of publishing, who would soon boast that he had sold one hundred million Little Blue Books, ${ }^{113}$ could offer Darrow the literary fame and widespread publication he longed for.

Darrow had a good deal to offer Emanuel as well. Both men were a mass of philosophical and political contradictions. Both were antiorganized religion; both were champions against what they called "bunk," that is, ignorant and fallacious theories propagated to the American public; and both were generally pro-labor. ${ }^{114}$ Interestingly,

107. Marcet Haldeman-Julius, Famous and InTEResting Guests of a KanSas Farm 17 (E. Haldeman-Julius ed., 1936).

108. Cothran, supra note 61, at 234.

109. Haldeman-Julius dedicated the September 1925 issue of the Haldeman-Julius Monthly to Clarence Darrow. The cover of the issue reads "This Number is Dedicated to That Brave Lover of Freedom and Enemy of Ignorance and Bigotry[:] CLARENCE DARROW." 2 HALDEMAN-JULIUS MONTHLY No. 4 (E. Haldeman-Julius ed., 1925).

110. See generally TIERNEY, supra note 1, at 390-97, 399-408 (describing Darrow's financial situation before and after the 1929 stock market crash). "The success Darrow sought was not material. Reputation had always come before riches, fame before fortune. His only interest in money was to have enough not to need to think about it." Id.

111. E. Haldeman-Julius, My FiRSt 25 Years, supra note 61, at 26-27.

112. See MORDELL, supra note 49, at 3 ("He was a great criminal lawyer, though he preferred to be an author.").

113. See generally E. Haldeman-Julius, The First Hundred Million, supra note 61 (detailing book sales for 1927, two years after Darrow first visited him in Girard).

114. See E. Haldeman-Julius, My FirSt 25 Years, supra note 61, at 27-29; E. Haldeman- 
while both were to the left politically and championed leftist causes, both also were, in their hearts, capitalists; never hesitant to earn a dollar for their labors. ${ }^{115}$ In 1925, Darrow was old enough and wealthy enough not to be much concerned with earning more money. ${ }^{116}$ He wanted lasting fame and a positive legacy. ${ }^{117}$ Emanuel, on the other hand, was still a young man with a family and had many ambitions for his business. He recognized that Darrow was a national figure and that the Scopes evolution trial had once again brought Darrow to center stage in the "great American parade," as Emanuel liked to call it. ${ }^{118}$ Emanuel could make money from printing Darrow's works. Indeed, Darrow refused to take any compensation from Emanuel and was even willing to furnish the stenographic transcripts that had been made of his performances in court and on the platform. ${ }^{119}$ This was a partnership made in heaven. Darrow gained fame and, at last, an outlet for all his writing. Emanuel gained a new, prominent author in his publishing stable and, even better, one who took no pay. The Darrows' 1925 visit to Girard was not the first and only. They returned again to the supportive environment on later trips. ${ }^{120}$

\section{REPORTING ON DARROW}

After the Scopes trial and the Darrows' visit to Girard, HaldemanJulius Publishing became the world center of reporting on the doings of Clarence Darrow, an activity that lasted for the next twenty-five years, even after Darrow's death in 1938. The principal Haldeman-Julius reporter assigned to Darrow was none other than Marcet HaldemanJulius, Emanuel's wife, who was now producing numerous articles for the Haldeman-Julius periodicals and writing and editing Little and Big Blue Books as well. ${ }^{121}$

Marcet's first major effort at covering Darrow began with a series of articles she published in the Haldeman-Julius Monthly between

JULIUS, THE OUTLINE OF BUNK 3-11 (1929).

115. E. Haldeman-Julius, My First 25 Years, supra note 61, at 27-28; E. HaldemanJULIUS, THE OUTLINE OF BUNK, supra note 114, at 379 ("[I]n our day a Mencken, a Nathan, or a Darrow will offer us a debunked, intelligent view of life that is more desirable than all the imposing philosophic systems ever created.").

116. See supra note 110 and accompanying text.

117. See supra note 110 and accompanying text.

118. E. HALDEMAN-Julius, The Big AMERICAN PARAde 35-37 (1929).

119. MORDELL, supra note 49, at 3, 6-7.

120. See id. at 6.

121. See, e.g., MARCet Haldeman-Julius, Great Court Trials of History (1937); MARCET HALDEMAN-JULius, THE LindBERGH-HAUPTMANN KidNAP-MuRdER CASE (1937). 
September 1925 and July 1926. These were then issued together as Big Blue Book B-29 in $1927 .{ }^{122}$ In these articles, she reported not only on the Scopes trial, but also on the racially explosive Chicago murder trial of Henry Sweets. ${ }^{123}$ Marcet was not only a firm supporter of Scopes and Sweets in her reporting, but she was also laudatory about Darrow:

I never shall forget my first impression of Clarence Darrow. As he and Emanuel emerged from the Mansion and came toward me I thought to myself: [t]aller than I supposed; a noble head; big, broad, slightlystooped shoulders; a kindly face with deep-set blue eyes-they twinkle - a face like creased leather, scarred with the lines of a long and exciting lifetime; long-palmed hands with sensitive fingers; rather thin, not too carefully brushed, only slightly grey hair....

Marcet was obviously smitten with Darrow and she portrays him as a great American hero.

In fact, Marcet's reports of Darrow's courtroom performances, accompanied by the transcripts supplied by Darrow, provided HaldemanJulius's readers with the closest thing to actually being present in the courtroom itself. The combination of Marcet's commentary with Darrow's speeches was powerful propaganda for Darrow and his causes. From Marcet's point of view, reporting on Darrow was an apprenticeship of sorts. After the Scopes trial, Marcet became the de facto "legal correspondent" for Haldeman-Julius Publishing. She went on to publish accounts of other major trials, including the Lindbergh-Hauptmann kidnapping trial. ${ }^{125}$

Although Marcet was the primary Haldeman-Julius author writing about Darrow, Emanuel himself wrote short pieces about him and also used other authors who had something special to offer. In May 1929, for instance, Haldeman-Julius published an article by George G. Whitehead. ${ }^{126}$ Whitehead was Darrow's tour promoter, responsible for Darrow's series of lectures and debates, many of which were to be published as Blue Books. ${ }^{127}$ The title of the article was Clarence

122. M. Haldeman-Julius, Clarence Darrow's Two Great Trials, supra note 103.

123. M. Haldeman-Julius, Clarence Darrow's Defense of a Negro, in ClARENCE DARROW'S TwO GREAT TRIALS, supra note 103, at 45-74.

124. M. Haldeman-Julius, Impressions of the Scopes Trial, supra note 103, at 7.

125. See M. Haldeman-Julius, The LindBergh-Hauptmann Kidnap-Murder Case, supra note 121 , at $68-100$.

126. George G. Whitehead, Clarence Darrow-The Big Minority Man (E. HaldemanJulius ed., 1929).

127. Id. (providing an overview of nine of Darrow's debates with which Whitehead was connected). 
Darrow-The Big Minority Man. ${ }^{128}$ It is a sympathetic account of the behind the scenes activities of one of Darrow's speaking tours. It gave quite a few insights into Darrow in old age, including some rather sad accounts of Darrow's feeling that he was tired and ready to die whenever death should come. ${ }^{129}$ The article, of course, was also terrific publicity for the Blue Books containing Darrow's speeches and debates.

Emanuel himself wrote at length about Darrow in the first installment of his autobiography, My First 25 Years, published as Big Blue Book B-788 in 1949:

Darrow, without a doubt, was the wittiest, most humorous man I've ever known.

He never granted favors, nor expected them. It was fight, fight, fighta constant, endless, tireless pounding away at the facts ....

Darrow loved to write, lecture and debate. The perfect extrovert, he liked to meet crowds ....

Darrow wasn't a Socialist or a political or social radical, but felt sympathy for all leftists, including the Anarchists. ${ }^{130}$

Darrow had no need for a press agent once he visited the HaldemanJulius farm in Girard in 1925. From that moment until his death, Marcet and Emanuel became his greatest promoters, his publishers, and his greatest admirers.

\section{PUBLISHING DARROW}

From an early age, Clarence Darrow wanted to become a writer and literary man, but he was strong as an orator, not an author. Although Albert Mordell, the author of a pamphlet about Emanuel and Darrow in the Big Blue Books series, states that Darrow had done little writing before he met Emanuel, ${ }^{131}$ this is unfair. Throughout his life, Darrow had written articles for popular magazines and published several books,

130. E. HALDEMAN-JULiUS, My FirST 25 YeARS, supra note 61, at 26-27.

131. MORDELL, supra note 49, at 3. 
including his collection of essays, A Persian Pearl ${ }^{132}$ his semiautobiographical novel, Farmington; ${ }^{133}$ his novel, An Eye for an Eye ${ }^{134}$ and, of course, his exposition of political, religious, and philosophical ideas couched in the form of an autobiography, The Story of My Life. ${ }^{135}$ Darrow's problem was not productivity. He could write and did write quite a bit. Unfortunately, no matter how prominent he became, he found it difficult to find major publishers for his books. And once he had found someone to publish the books, the books tended to be neither critical nor popular successes. In many ways, Darrow was very much the model of a failed writer. Given his large ego and craving for recognition as a serious writer, this must have been a great sadness to him. When, in 1925, he renewed his friendship with Emanuel, Darrow, at last, found an outlet for his various writings. More importantly, Haldeman-Julius Publishing was a mass marketer of his publications and could ensure Darrow's works would be widely advertised and distributed. The Haldeman-Julius publications also served as advertising for Darrow's speeches and debates, ensuring he would have a large crowd at every performance.

Certainly, Haldeman-Julius Publishing invested both time and money in printing Darrow's works. The range of the work printed is quite astonishing. Haldeman-Julius obtained the rights to reprint a number of Darrow's works that had gone out of print. They printed the trial transcripts of Darrow's noted trial orations. They reprinted several of Darrow's periodical pieces, and, of course, they printed the transcripts of a number of Darrow's debates. In all, Haldeman-Julius published twenty-two Little Blue Books by Clarence Darrow. ${ }^{136}$ Of these, twentyone were published between 1925 and $1931 .{ }^{137}$ One, a transcript of a speech given to the Rationalist Society of Chicago, Insects and Men: Instinct and Reason, was published earlier, in 1920. ${ }^{138}$ Haldeman-Julius also published an abridged version of Darrow's novel Farmington ${ }^{139}$ in 1925, and a debate entitled Does Man Live Again? in $1936 .{ }^{140}$ It also

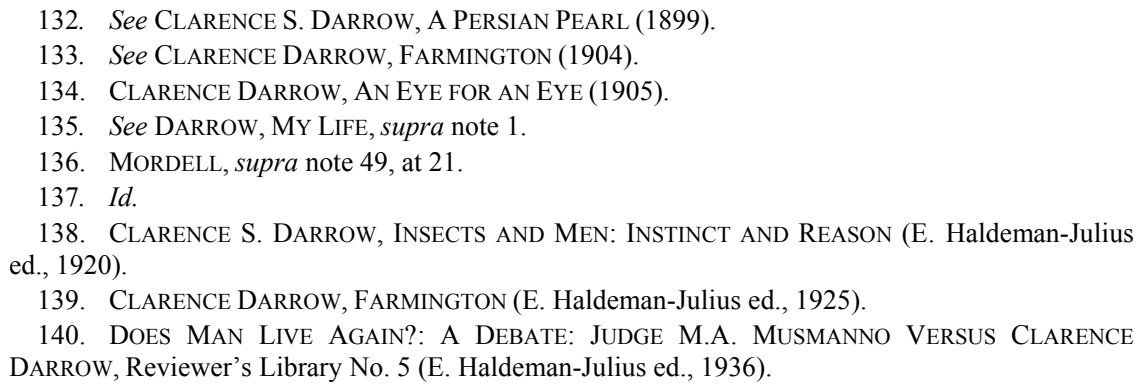


reprinted one of Darrow's essays, The Rubaiyat of Omar Khayyam, from A Persian Pearl, in Little Blue Book No.1, as early as $1919 .{ }^{141}$

Although Haldeman-Julius published at least two essays by Darrow before 1925, the vast majority of Darrow's works appear in HaldemanJulius editions between 1925 and 1931, after the Scopes trial and the Darrows' visit to the Haldeman-Julius farm. ${ }^{142}$ No doubt, it was this visit to Girard during which Emanuel and Darrow spent hours deep in conversation that led to the ambitious publishing program of the next six years. ${ }^{143}$ But it would be naive to think that Haldeman-Julius published so many of Darrow's works during this period solely because of their friendship or Emanuel's admiration for Darrow. It seems undeniable that the publications from 1925 to 1931 were issued to take advantage of the public's massive interest in Darrow after he defeated William Jennings Bryan in Dayton, Tennessee. We know the Scopes trial was reported extensively in the news media across the United States. After the trial, Clarence Darrow became a household name; ${ }^{144}$ the pattern of publication dates within this period confirms this. Seven of the Little Blue Books by Darrow were published in 1925, the year of the Scopes trial. ${ }^{145}$ One must also keep in mind that Haldeman-Julius's publishing plant was immensely efficient and capable of producing tens of thousands of books each week. ${ }^{146}$

Fortunately, Haldeman-Julius provided Albert Mordell with sales figures for many of Darrow's books that he published. The best seller of these was the Dry-Law Debate, which had sold 241,250 copies by $1950 .{ }^{147}$ The next best seller by Darrow was Insects and Men, which sold 160,000 copies, followed by his essay entitled Is Life Worth Living?, which sold 112,000 copies, and his Debate on Capital Punishment, which sold 103,500 copies. ${ }^{148}$ All of the other works sold fewer than 100,000 copies. ${ }^{149}$ None of these were outstanding best sellers by Haldeman-Julius's standards, but they did approach the sales of many of the Little Blue Books on sex and self-help topics. ${ }^{150}$ Nevertheless, Darrow reached hundreds of thousands of Americans, mostly working-

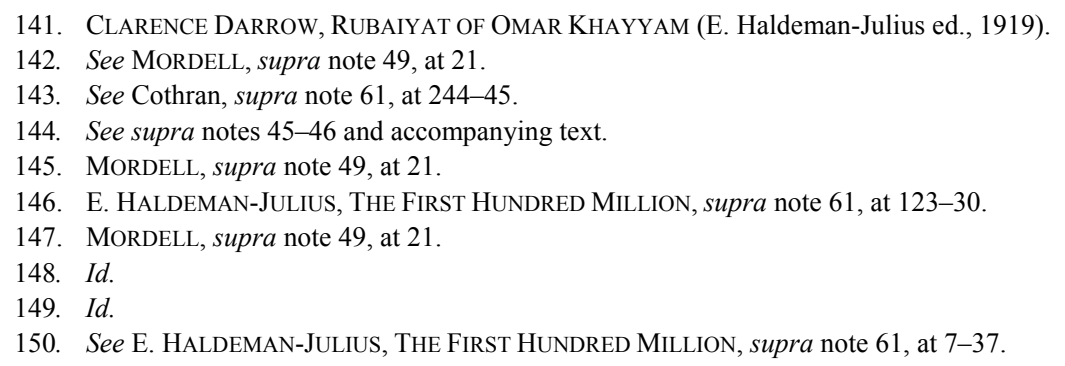


class or middle-class people who would not otherwise have had access to his writings.

\section{DARROW \& KANSAS}

Even after Clarence Darrow's death in 1938, Emanuel HaldemanJulius continued to keep Darrow's works in print, advertise them, and even published a volume with an introduction by John Gunn, one of Emanuel's regular authors, entitled The Wisdom of Clarence Darrow. ${ }^{151}$ For twenty-five years, Emanuel and Darrow remained friends. During Darrow's period of disgrace, Emanuel defended him in the socialist press, even though Darrow was not a socialist. More importantly, at the end of Darrow's life, when he had attained fame and wealth through his law practice, Emanuel was able to provide him with the one thing that had eluded Darrow previously: a large readership for his written works.

In 1929, after the Scopes trial and at age seventy-two, Darrow published an article in The Saturday Evening Post entitled What Life Means to Me at Seventy-two. ${ }^{152}$ It is a moving essay, for it shows the world-weary crusader - the atheist with no expectation of a hereafter-in a self-reflective and philosophical mood. Two passages from this essay bear especially on his relationship with Emanuel. In the first he expresses the essence of what keeps his zeal for living so strong:

As a propagandist, I see no chance to grow weary of life. I am interested in too many questions that concern the existence and activity of the human race. Not only am I interested in these questions but, for some reason or other, I almost always find myself disagreeing with the crowd. ${ }^{153}$

In the second, he reflects on friendship:

The older person finds contentment and happiness in friends who help him enjoy the evenings now at hand. Beguiled by fond friends and interesting discussions that would have been stupid in youth, time passes all too quickly, and there follows the feeling of relief at the approaching sleep.

151. See The Wisdom of Clarence Darrow (E. Haldeman-Julius ed., 1947).

152. Clarence Darrow, What life Means to Me at SeVenty-two (reprinted from The Saturday Evening Post) (1930). Haldeman-Julius Publishing reprinted this article as Little Blue Book 1541. Id.

153. Id. at $12-13$.

154. Id. at 7-8. It is noteworthy that this same Little Blue Book, on pages nineteen through 
Emanuel was able to provide Darrow with both of these pleasures of his old age. At a time when he could no longer stand the rigorous demands of high-profile litigation, Emanuel was the key to Darrow's ability to continue his career as a propagandist. By publishing his essays, speeches, and debates, Emanuel not only got Darrow an enlarged audience, but also transmitted Darrow's most strongly held beliefs to hundreds of thousands of readers. Month after month, Emanuel devoted full page advertisements in his periodical to Darrow's works. An example of such an advertisement is found in Marcet's account of the Lindbergh-Hauptmann case published in 1937, just one year before Darrow's death, which reads:

He denounces people's pet notions and makes them like it! ... Here are books that will startle you into new lines of thought! A handy pocket library of books of liberal viewpoint! Best liberal reading 1,157 Pages, 300,000 Words-Almost Two Pounds-for $\$ 1.00$ !

How could Darrow, the propagandist, not have been delighted by all of this?

But of Darrow's two pleasures of old age, friendship also came with his connection to Emanuel and Girard, Kansas. It was precisely when Darrow was in his late sixties that he began his trips to Girard and the Haldeman-Julius farm. It was here that Darrow and Emanuel could spend hours debating the issues that interested them both. When we see the photographs taken on these visits, it is impossible not to see the deep connection between the old lawyer and the young publisher. It is easy to imagine the two of them sitting on the porch in Girard, smoking cigars and speaking of philosophy, religion, and politics.

\section{CONCLUSION}

While Clarence Darrow did not spend very much time in Kansas, his connections to the state were deep and critical to his life, his career, and his legacy. If we cannot claim Darrow as one of our own, we can, at least, insist that Kansas played an important and valued role in the life of this iconic member of the legal profession.

thirty-two, contains E. Haldeman-Julius's What I Think of Darrow at Seventy-two. Id. at 19-32.

155. See M. Haldeman-Julius, The LindBergh-HauptMann KidnAP-Murder Case, supra note 121 , at 101 . 


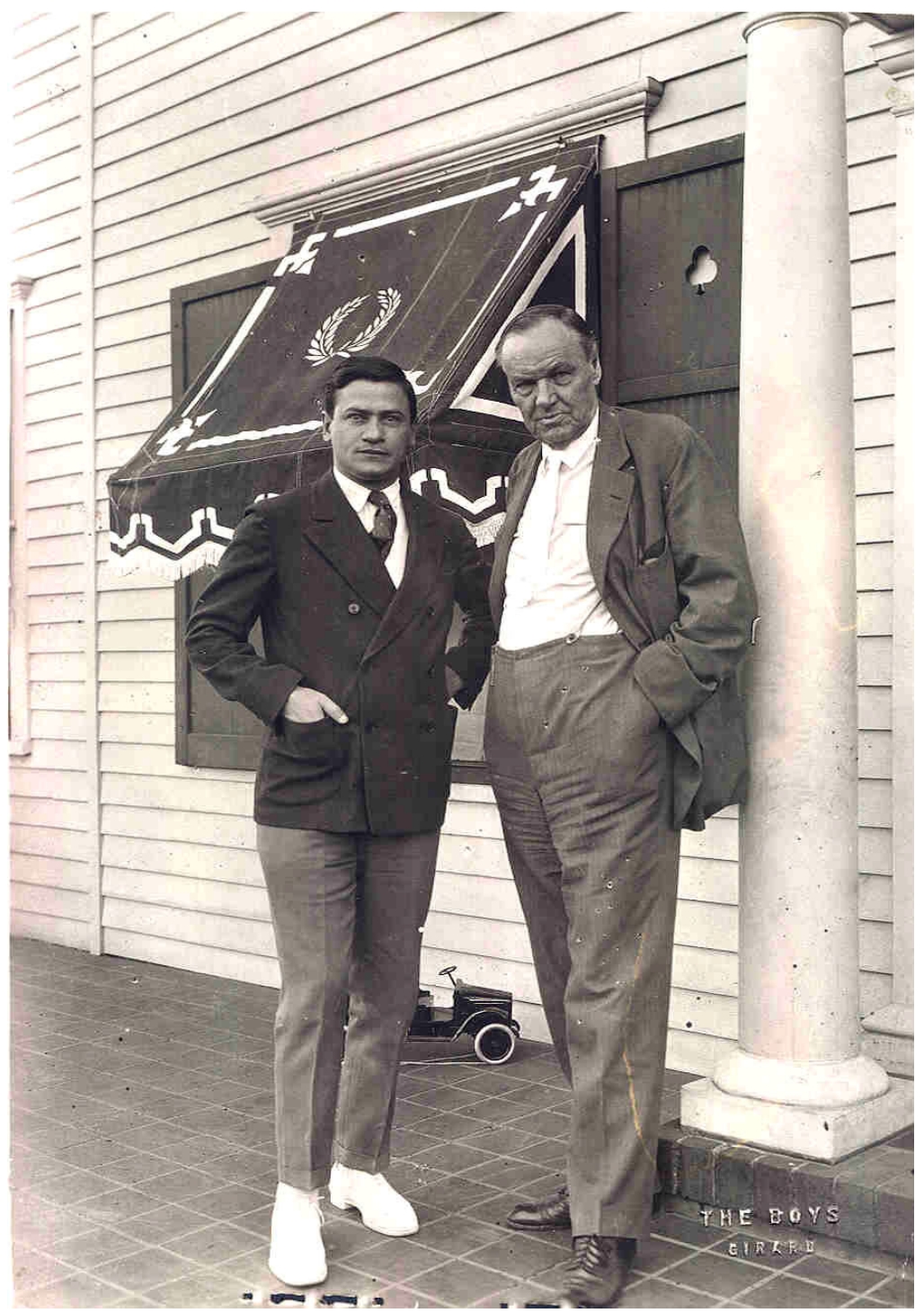

Emanuel Haldeman-Julius and Clarence Darrow at the Haldeman-Julius Home near Girard, Kansas, in 1925.

Photograph Courtesy of the Haldeman-Julius Collection, Leonard H. Axe Library, Pittsburgh State University. 


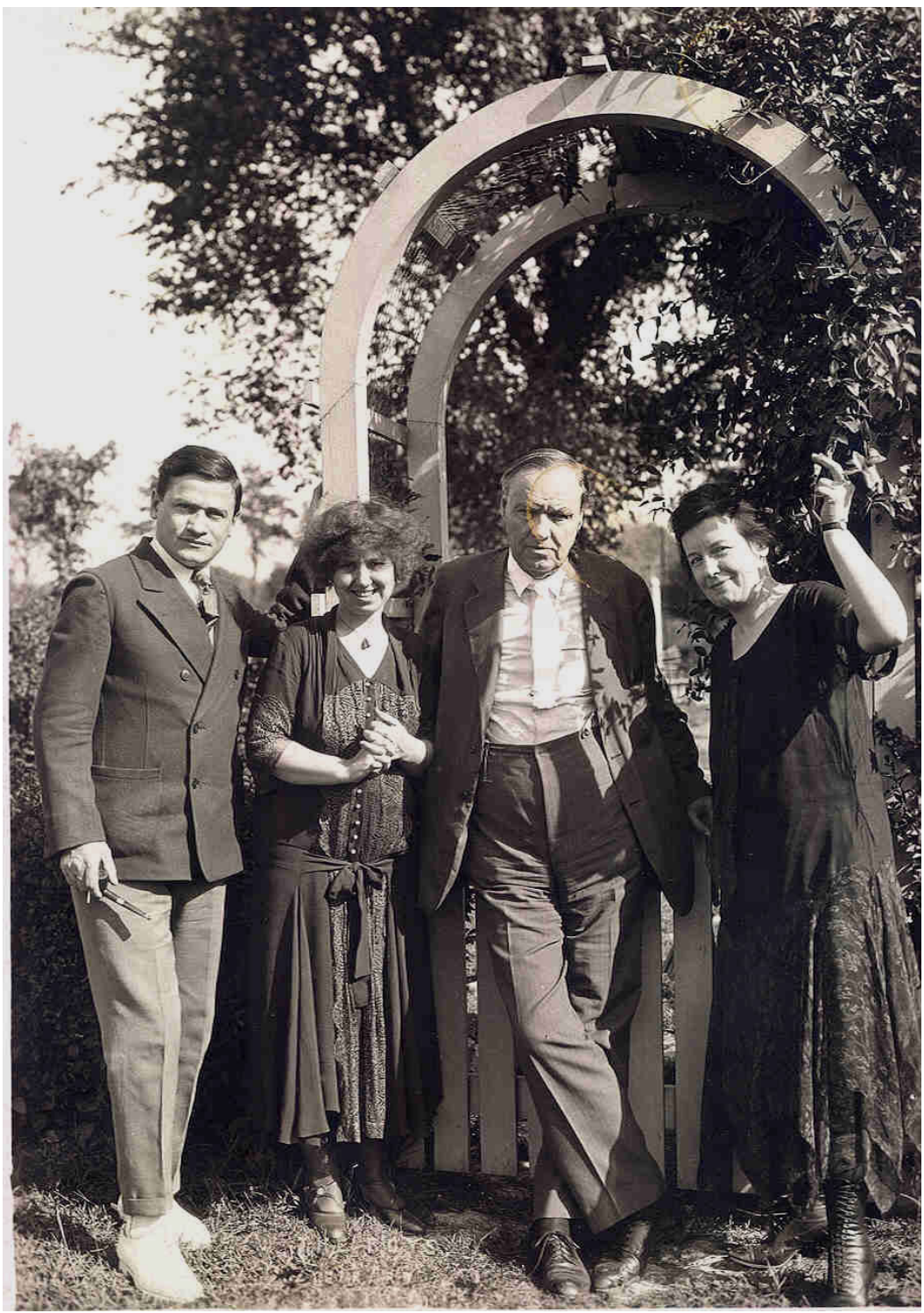

Emanuel and Marcet Haldeman-Julius, Clarence and Ruby Darrow, at the Farm near Girard, Kansas, in 1925. Photograph Courtesy of the Haldeman-Julius Collection, Leonard H. Axe Library, Pittsburgh State University. 


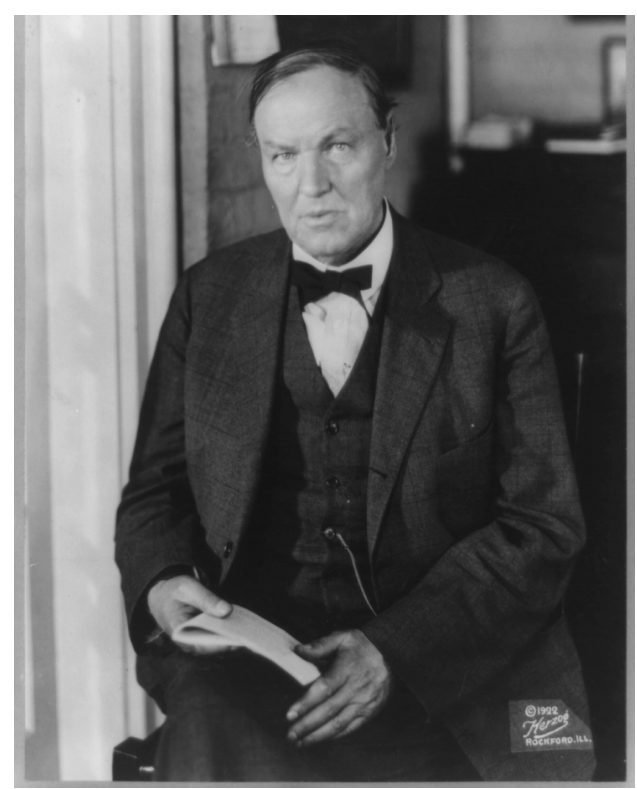

Clarence Darrow, 1922.

Photograph from Library of Congress Portrait Collection.

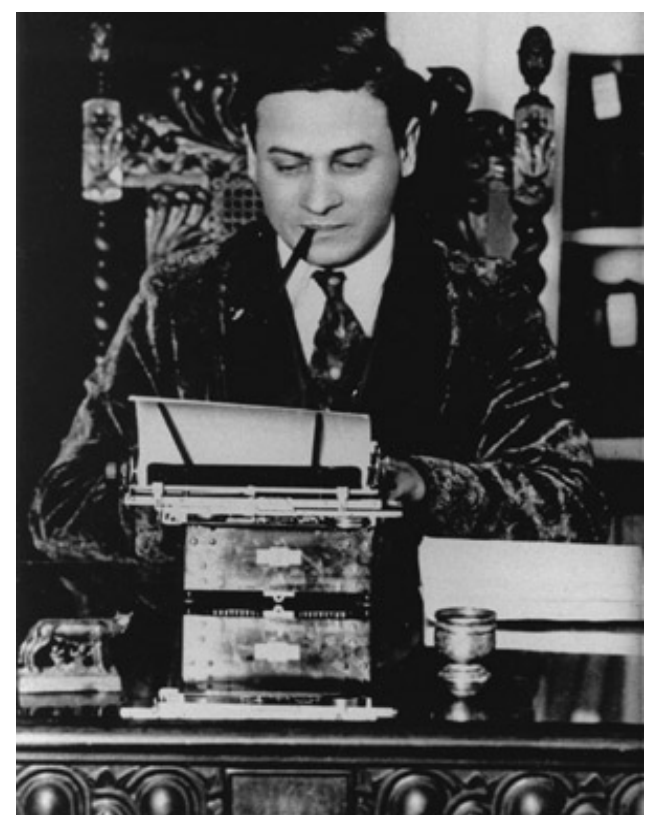

Emanuel Haldeman-Julius at His Typewriter, 1925

Photograph Courtesy of the Haldeman-Julius Collection, Leonard H. Axe Library, Pittsburgh State University. 